\title{
AGNIESZKA SZCZAUS
}

Uniwersytet Szczeciński

\section{JEZZYKOWY KSZTAŁT PORADNIKA GOSPODARSKIEGO POMIESZCZONEGO W, „NOWYCH WIADOMOŚCIACH EKONOMICZNYCH I UCZONYCH” (1758-1761)}

Wydawane w Warszawie w latach 1758-1761 „Nowe Wiadomości Ekonomiczne i czone"l były wzorowanym na periodykach zachodnioeuropejskich pierwszym polskojęzycznym czasopismem o charakterze popularyzatorskim, określanym mianem czasopisma półuczonego (na wzór niem. Zeitschrifte halbgelherte) (Kurkowski 1994: 53). Redaktorem i wydawcą „Nowych Wiadomości” był Saksończyk z Lipska Wawrzyniec Mitzler de Kolof $^{2}$, z wykształcenia muzyk i medyk, który trafił do Polski na początku lat 40. XVIII wieku do majątku Jana Małachowskiego w Końskich w charakterze nauczyciela domowego. Pod koniec lat 40. W. Mitzler przeniósł się do Warszawy, gdzie m.in. prowadził praktykę lekarską, ale też nawiązał kontakt z Biblioteką Załuskich. Współpraca z Biblioteką zaowocowała wydaniem pierwszego w Polsce niemieckojęzycznego czasopisma uczonego (niem. Zeitschrifte gelherte) zatytułowanego „Warschauer Bibliothek”. Następnie W. Mitzler redagował łacińskojęzyczne czasopismo uczone pt. „Acta Litteraria”, by wreszcie rozpocząć pracę nad polskojęzycznym pismem o charakterze popularyzatorskim, to jest właśnie nad „Nowymi Wiadomościami”. W założeniu miał to być miesięcznik, ale nie ukazywał się regularnie - w ciągu 4 lat przygotowano 12 numerów pisma. Cel wydawania miesięcznika redaktor wyraźnie określił już w Przedmowie pomieszczonej w pierwszym numerze pisma, gdzie czytamy:

żadnego prawie w całey Europie Pańltwa nie nayduyem, gdzieby mieflięczne Pifma, abo ofobliwe o umiejętnościach wiadomości na każdy mieliąc wydawane nie były [...]. Pollka dotychczas, (nie wiem dla iakiey czafow przeciwności) Pism tych miefięcznych mieć nie mogła. Cudzoziemcy małą zawfze wiadomość o Naukach w Polfzcze kwitnących miewali, a Polacy iefzcze mnieyfzą o Naukach i uczonych dziełach Cudzoziemcow [...]. Polakom o teraznieyfzym wydofkonaleniu

\footnotetext{
${ }^{1}$ Pełny tytuł czasopisma brzmi: „Nowe Wiadomości Ekonomiczne i Uczone albo Magazyn wszystkich nauk do szczęśliwego życia ludzkiego potrzebnych, wydane przez Wawrzyńca Mitzlera de Kolof, filozofii i medycyny doktora, historii Rzeczypospolitej pisarza, różnych Akademii cudzoziemskich towarzysza J.K.M.K“"

2 Informacje o Wawrzyńcu Mitzlerze za: Klimowicz 1953: 228-277; Aleksandrowska 1976: 389-392.
} 
nauk w cudzych Kraiach wiadomość dać myślę, oyczyfta do tego mowa nayfpofobnieyfza być fię zdała, aby ztąd nie tylko uczeni, lecz i mniey w naukach biegli ludzie, pożytek mieć mogli³.

W dalszej części Przedmowy W. Mitzler wyjaśnia jeszcze, że do szczęścia prowadzą trzy drogi: zdrowie, bogactwo i mądrość. Dlatego też w „Nowych Wiadomościach” publikowano artykuły oryginalne oraz przedruki (tłumaczenia) tekstów niemieckich i francuskich, w których poruszano głównie problemy z zakresu medycyny, ekonomii (w tym z rolnictwa, przemysłu i handlu) oraz filozofii. Część artykułów pomieszczonych w „Nowych Wiadomościach" jest opatrzona nazwiskiem W. Mitzlera, choć badacze nie są pewni, czy Saksończyk znał polszczyznę wystarczająco dobrze, by samodzielnie pisać i redagować teksty (Kurkowski 1994: 53).

Celem poniższego artykułu jest językowa analiza poradnika ${ }^{4} \mathrm{z}$ zakresu gospodarstwa, sygnowanego przez W. Mitzlera, a zamieszczonego w „Nowych Wiadomościach”. Poradnik ten składający się z rozważań wstępnych oraz dziesięciu rozdziałów drukowanych w kolejnych numerach miesięcznika (od numeru 1 poczynając) tworzył spójną tematycznie całość obejmującą: ekonomiczne podstawy prowadzenia gospodarstwa, przygotowanie roli i uprawę roślin. Poszczególne rozdziały były spięte wspólnym, choć niekonsekwentnie przywoływanym tytułem: Wstęp do ekonomii albo gospodarstwa porządnego (rozważania wstępne oraz rozdział I), Wstęp do gospodarstwa porządnego (rozdziały IV, V i VI) lub najczęściej Wstęp do gospodarstwa (rozdziały II, III, VII, VIII, IX i X). W części wprowadzającej poradnika (s. 29-38) W. Mitzler wyjaśnia podstawowe pojęcia związane z ekonomią, dzierżawą majątków, dochodami, wydatkami itp. Rozdziały pierwszy, drugi i trzeci poradnika (tj. I O poznawaniu gruntów, s. 38-42; II O sposobie wyprawowania roli, s. 106-115; III Jakim sposobem miejsca opuszczone wyrabiać, s. 208-215) dotyczyły gleboznawstwa, z kolei rozdziały od czwartego do dziesiątego (IV O pszenicy ozimej i jarej, s. 433-439; V O życie ozimym i jarym, s. 440-442; VI O jęczmieniu ozimym $i$ jarym, $i$ o owsie, s. 443-446; VII O grochu, wyce, prosie, konopiach, Inie, i rzepie białej, s. 501-512; VIII O gryce, tartoflach, kalarepach i jarmużu, s. 561-569; IX O marchwiach, s. 569-573 oraz X O mieszaniu z nasion marchwi, pietruszki, korzeni, pasternaku, buraków korzeni słodkich, cybuli, anyżu, bożej trawki, gorczycy, kminu polnego, kminu czarnego, rzeżuchy, maku, krokosu, \&c., s. 573-576) poświęcone były uprawie zbóż i innych roślin jadalnych. Analiza powyższego poradnika zostanie przeprowadzona na płaszczyźnie strukturalnej, pragmatycznej, poznawczej i stylistycznej. Metodologiczne założenia analizy przyjęto za Marią Wojtak (1999; por. też Witosz 2005: 161-163).

${ }^{3}$ Ten i następne cytaty z „Nowych Wiadomości“ przywołano za egzemplarzem udostępnonionym przez Bibliotekę Narodową (sygn. Czart. I 33134). Utrzymano oryginalną pisownię; podkreślenia w cytatach - A.Sz. W nawiasie kwadratowym za cytatem podano numer strony, z której pochodzi przytoczenie. Przedmowa dołączona do tekstu znajduje się na stronach nienumerowanych.

${ }^{4} \mathrm{Na}$ użytek poniższych rozważań użyto określenia gatunkowego poradnik wbrew tradycji nazewniczej XVIII wieku, kiedy to poradnik oznaczał osobę 'co radzi, radę daje', a nie typ tekstu (por. SL IV 353). 


\section{Strukturalny aspekt poradnika}

Poszczególne części poradnika mają charakter rozważań teoretycznych (chodzi o wprowadzenie do poradnika, w którym wyjaśniono podstawowe pojęcia ekonomiczne oraz rozdział I $O$ poznaniu gruntów) lub rozważań teoretycznych połączonych z praktycznymi poradami (pozostałe rozdziały). Partie tekstu, zarówno te o charakterze teoretycznym, jak i praktycznym, mają uporządkowaną, dość schematyczną, powtarzalną strukturę. W części wstępnej poszczególnych rozdziałów w pierwszej kolejności pojawiają się swego rodzaju hasła (np. żyzność ról, s. 106; oranie, s. 110; kanat do wysuszenia miejsca błotnistego, s. 210 itp.) zapowiadające problem, którego będzie dotyczył dany akapit tekstu. Hasło to może, choć nie musi, być zdefiniowane. Definicje nie są tu elementem obligatoryjnym objaśnione zostały tylko podstawowe pojęcia z zakresu ekonomii, takie jak np.: ekonomia (s. 29), ekonomia wieśniacza (s. 35), środki sprawiedliwe (s. 31), środki niesprawiedliwe (s. 31) oraz wybrane pojęcia z zakresu rolnictwa, np.: zagony (s. 110), ugór (s. 113), pszenica ozima (s. 433), kalarepa (s. 566) itp. W sumie w poradniku objaśniono 22 pojęcia. Definicje obecne w poradniku mają trójdzielną budowę - składają się z definiendum (członu definiowanego), definiensa (członu definiującego) oraz łącznika (członu spajającego w wypadku definicji pomieszczonych w poradniku funkcję łącznika pełni czasownik być w odpowiedniej formie) $)^{5}$, np.: „Tartofl ieft owoc nadoł w ziemi rofnący, niedawnego czafu w Niemczech nayprzod, a potym i w Polfzcze rozmnożony ieft" [564]; ,zagony fą częśći roli z dziefięciu, dwunaftu, piętnaftu, i dwudzieftu brózd zrobione, we śrzodku wyżlze, a z obu ftron niżlze, które ma dzielić iedna brozda głębiey niż inne zapufzczona w ziemię" [110-111].

Definicje mogą być poszerzane o dodatkowe wyjaśnienia, np.: rzeczownik ekonomia został zdefiniowany następująco: „Ekonomia ieft nauka nabywania, i pożytecznie fzafowania majętności" [29]. Do definicji tej dołączone zostało dodatkowe objaśnienie, wyraźnie wydzielone graficznie za pomocą mniejszej czcionki: „Gdy Ekonomią nazywamy nauką, nie rozumiemy przez to owey umiejętności pofpolitey, którą prawie wfzyfcy wieśniacy i golpodarze maią: o takiey tu nauce mowiemy, którey przez pewne reguły obiaśniaiąc ekonomią, możemy iey porządnie do zamierzonego końca zażywać. Ta nauka obfzerniey wzięta ieft prawie nielkończona, bo do wfzyftkich dobr, i majętności, które fię natym świecie znayduią; ściągać może, i iey umiejętność, około obory, zboża, lafow, i minerałow po Filozoficku opifana, ieft potrzebna" [29-30].

Po definicji (lub niekiedy zamiast niej) następuje szczegółowa charakterystyka przedstawianego obiektu czy zjawiska. Charakterystyka taka przybiera postać krótkich opisów i wyliczeń, np.: ,infze ieft gofpodarftwo w wiofkach, infze w miaftach, infze w ftaniech rzeczypofpolitey, infze panujących, przetoż na cztery częśći dzieli fię ekonomia, to ieft na wieśniaczą, mieylką, Dworfką i stanow Rzeczypofpolitey” [35]; „Ekonomia wieśniacza z dwóch częśći znacznieyfzych fkłada fię, to ieft, z roli, i bydła” [36]; „Do ekonomii wieśniaczey potrzebny ieft folwark, któryby miał role, ląki, paftwilka, lafy, i budynki, żeby ztąd dochod tym więkfzy mogł być zbierany" [36] itd. Wyliczenia mogą być dodatkowo wypunktowane (co zwiększa przejrzystość tekstu) oraz wyróżnione graficznie za pomocą odmiennego kroju i rozmiaru czcionki. Na przykład z rozdziału o rodzajach gleby dowia-

\footnotetext{
${ }^{5}$ O budowie definicji por. np.: Żmigrodzki 2009: 81-82.
} 
dujemy się, że „Każda rola, albo ieft dobra, albo mierna, albo podła” [38], po czym następuje dokładny opis każdego rodzaju roli, np.:

„§ XXIII. Znaki Ziemi naylepґzey.

I. Ziemia czarniawa, mięka, nie bardzo lgnaca, i łatwo wilgoć przypufzczaiaca, dobra ieft.

II. Ziemia fzara, nieco ciemno żołtawa, trocha mulista, thusta fie pokazujaca, przyciężka, lgnaca, jednak w ręku tarta, łatwo rozcierajaca fię, ieft iejzcze lepsza.

III. Ziemia bladawa, daiąca lie na fucha łatwo trzeć, ciefzka $w$ ręku, i podczas wilgoci zdaiaca fię ttusta, mało co lśniąca fię, równie ieft dobra.

IV. Ziemia ciemno czerwonawa, nieco mulista, cięzka i łatwo rozcierajaca fię, także ieft dobra" [38-39].

Niekiedy charakterystyka taka jest poszerzona o pouczenia, wskazówki moralne, np.: „Maiętność albowiem przez to tylko ieft dobra i pożyteczna, że ieft śrzodkiem koniecznie potrzebnym do dzieł chwalebnych” [31]; „Nabywać majętności przez fprawiedliwe tylko śrzodki powinniśmy" [31].

Po rozważaniach teoretycznych następują porady praktyczne z zakresu gospodarstwa, na które składa się pięć następujących elementów: a) określenie czynności, b) określenie czasu wykonania czynności, c) określenie miejsca, d) określenie sposobu wykonania czynności oraz często e) elementy perswazji (pouczenia, argumenty), np.: „§ V. Dogodny fiewu czas ieft koło świętego Michała, to ieft po fprzątnionym zaraz żniwie, kiedy Pfzenicę nad inne doftalfzą do ftodoł zwożą, i wyżey namienionym fpofobem odkładają. § VI. Do fieyby nie inne, tylko nayświeżfze ziarno ma być brane. Doświadczenie nauczyło, że ziarno, co przez rok lub trzy lata było chowane, ledwie przez połowę wfchodzi; dlaczego oftrożny Ekonom, tak nayświeżlze tylko ziarno, i naylepґze ma wybierać" [433]. Model strukturalny porady jest zatem stosunkowo prosty - jest to pięć wymienionych powyżej elementów, które jednak nie muszą występować w każdym akcie doradzania. Wariantami fakultatywnymi są porady ograniczone nawet do jednego tylko elementu, to jest do wskazania czynności, którą należy wykonać, np.: „W wyrabianiu roli trzeba kamienie więkfze wybrać i z roli wynieść, wfzelkiego rodzaiu kąkol wykorzenić i wyrwać, ieśli lię iaki znayduie" [112-113].

Omawiane we Wstępie do gospodarstwa zagadnienia, zarówno teoretyczne, jak i praktyczne, są ujmowane w akapity, które są wyraźnie oddzielane, oznaczane znakiem paragrafu i numerowane - a więc segmentacja tekstu jest bardzo wyraźna. Zabiegi segmentacyjne wpływają w istotny sposób na organizację tekstu, poprawiają jego przejrzystość, narzucają pewien rytm, a dzięki temu ułatwiają potencjonalnemu odbiorcy poruszanie się po nim. Rytmizacji tekstu służą ponadto szablonowe tytuły rozdziałów, typowe dla literatury poradnikowej, rozpoczynające się przyimkiem o łączącym się z rzeczownikiem w miejscowniku (np. O marchwi, O życie ozimym i jarym, O sposobie uprawiania roli) - schemat ten został przełamany we Wstepie do gospodarstwa tylko jeden raz, w tytule: Jakim sposobem miejsca opuszczone wyrabiać.

Poszczególne rozdziały i akapity poradnika mogą być zamknięte formułą finalną (por. Dobrzyńska 1978: 101-118) - choć brak tu konsekwencji - zapowiadającą treść kolejnych rozdziałów lub paragrafów, np.: „W przyfzłym rozdziale będzie fię mowiło o fpofobie wyprawowania roli” [41]; „Role w Polfzcze na trzy dzielą fię rodzaie pofpolicie, na niektórych zaś mieyfach na cztery: ten podział ieft wielce pożyteczny, iako fię niżey pokaże" [107]. 
Można więc zauważyć, że elementy paratekstowe, to jest nadrzędny, powtarzający się tytuł całego poradnika (Wstęp do gospodarstwa), numer i tytuł rozdziału (np. Rozdział V. O życie ozimym i jarym) oraz numer paragrafu z jednej strony oraz wypowiedzenie finalne, w którym zapowiada się treść kolejnych partii tekstu z drugiej strony, stanowią wyrazistą ramę delimitacyjną kolejnych części poradnika, wpływającą w znaczny sposób na spójność i organizację analizowanego tekstu.

\section{Pragmatyczny aspekt poradnika}

Analizowany poradnik był przeznaczony dla określonej grupy odbiorców, to jest szlachty związanej z rolą. Odbiorca w tekście jest określany albo jako gospodarz (26 razy, np.: „Nie może gofpodarz zrozumieć ftanu maiętnośći, (...) ieśli nie pozna dolkonale proporcyi dochodow i wydatkow fwoich” [33]), albo rzadziej jako ekonom (8 razy, np.: „Ta rzecz ieft tak iafna z doświadczenia, iż o niey żaden Ekonom wątpić nie może" [106]). Ponadto odbiorca jest dookreślany za pomocą zaimków uogólniających: każdy (4 razy) oraz żaden (4 razy), np.: ,Te rzeczy tak fą iasne i pewne, że ie każdy bez dalfzego wykładu i potwierdzenia łatwo poznać może” [34]; „Wiadomo każdemu, iż nafzych czafow wiele mieyfc puftych w Litwie y w Polfzcze tak wyrobiono, iż teraz od ludzi zamiefzkane niemałe gofpodarzom pożytki przynofzą" [208]; „Żaden nie może ani bogactw, ani majętności nabyć, któryby wprzód nie ftarał fię tego co ma utrzymać” [31]; „Iakie ztąd do orania bywaią przefzkody, i trudności, że roli użyć nigdy dobrze nie można, żadnemu gofpodarzowi tayno być nie może" [215].

Nadawca porad sytuuje się w pozycji specjalisty, eksperta w dziedzinie rolnictwa, który dzieli się wiedzą oraz doradza ${ }^{6}$, instruuje, wydaje polecenia lub przyzwolenia na jakąś aktywność mniej doświadczonemu i słabiej wykształconemu czytelnikowi, a niekiedy nawet go poucza. Dystans między nadawcą a odbiorcą jest bardzo wyraźny, sygnalizowany m.in. dzięki wybranym formom czasownikowym (charakterystycznym zwłaszcza dla kształtującego się stylu naukowego i popularnonaukowego ${ }^{7}$ ), które jednocześnie mogą być wykładnikiem dyrektywności. Są to:

a) czasowniki w trybie rozkazującym. Należy jednak podkreślić, że w analizowanym tekście jest to najmniej liczna grupa (zaledwie 10 przykładów). Znamienne, że są to formy 3. osoby liczby pojedynczej lub mnogiej, budowane w oparciu o partykuły niech oraz niechaj, co jeszcze bardziej pogłębia dystans między nadawcą a odbiorcą, np.: „Jeśli ziemia ieft nie płodna, gofpodarz niech weyrzy w przyczyny tey nie płodności” [37]; „rolą kędy owies fiać będzie gofpodarz, niechay wprzód fłufznie uprawi” [445]; „w czaly niech go [owies] fieyą suche kiedy brozdy odkładane fą lżeyfze i wyfchle" [446]. W analizowanym

${ }^{6}$ Przyjęto tu stanowisko Ewy Ficek (2013: 85-87), która wyraźnie rozdziela rady (rada - przyjacielska, dobra, życzliwa) i porady (porada - specjalistyczna, ekspercka, fachowa, rzeczowa) oraz czynność radzenia (w wyniku której powstaje rada) i doradzania (w wyniku której powstaje porada). Nadawcą rady może być każdy, zaś nadawcą porady może być tylko ekspert, znawca w danej dziedzinie. Rozróżnienie rady i porady możliwe jest tylko na podstawie analizy kontekstu.

${ }^{7} \mathrm{Na}$ to, iż wybiórczość kategorii fleksyjnych czasownika jest charakterystycznym elementem stylu naukowego i popularnonaukowego, wskazuje wielu badaczy, np.: Gajda 1988: 29-39; Starzec 199: 187-198; Biniewicz 2002: 275-306. 
poradniku brak jest zupełnie rozkaźników w 2. osobie liczby pojedynczej lub mnogiej, tak charakterystycznych dla różnego rodzaju dyrektyw;

b) wypowiedzenia bezokolicznikowe w funkcji rozkaźnika (38 przykładów), np.: „Zniożlzy dochody pewne i niepewne połowę ich tylko na wydatki pewne i niepewne odłożyć, refztę zaś na potrzeby przypadkowe, zachować” [33]; „W każdym gofpodarftwie ftarać fię, abyśmy przez iedne śrzodki rożnych końcow i zylkow doftąpili” [35]; „Wkrótce potym czwarty i oftatni raz rolą zaorać, aby gnoy przegniły znowu wfzedł do ziemi, co uczyniwfzy zaraz nafienia zimowe w świeże oranie wrzucić, i pilnie zabronować” [113];

c) konstrukcje analityczne złożone z czasowników: mieć, można, móc, musié́, należy, nie zawadzić, potrzeba, powinien, powinno się, trzeba, wolno oraz bezokolicznika w funkcji rozkaźnika (najliczniejsza grupa - 222 przykłady), np.: „Tego zaś naybarziey Gofpodarz ma doyrzeć, [...] aby groch do fiewu był na wybor dobierany” [502]; „Około świętego Bartłomieia można iuż rzepę więkfzą wyrywać i kilka fur do miafta bliżlzego na przeday pofłać” [511]; ,Nie może gofpodarz zrozumieć ftanu maiętnośći, (...) ieśli nie pozna dofkonale proporcyi dochodow i wydatkow fwoich" [33]; „fą niektóre mieyfca, gdzie koniecznie mufza być zagony wąlkie” [111]; ,te przeltrogi zachować należy” [208]; „Dochody i wydatki iedne fą pewne, drugie niepewne: Pewnych łatwo doyść można: nie pewne zaś co fiedm lat znofić potrzeba, i ich fummę na fiedm częśći równych podzielić, takową część za fummę roczną wydatkow i dochodow niepewnych liczyć potrzeba” [33]; „Znalazfzy te przyczyny nie zawadzi zażyć fpofobow świeżo wynalezionych do uczynienia roli żyźnieyfzey” [37]; „lemiefz nie głębiey iak na trzy lub pół czwarta palca, a naywięcey na cztery palce do ziemi wniść powinien" [112]; "Trzeba uważać iż nie każda rola ieft tak dobra, aby na niey pґzenicę lub rzepnicę zimową można było zafiewać” [114]; „Tym fpofobem gofpodarftwo ułożywlzy, wolno zażywać fwych dochodow do wygod i wfpaniałośći życia" [34];

d) formy zaimkowe (zwrotne) czasownika w 3. osobie liczby pojedynczej lub mnogiej o nieokreślonym wykonawcy czynności (33 przykłady), np.: „[Tartofle] W Iefieni zaś około święta S. Marcina wykopuią fię” [565]; „Drugiego rodzaju rola ieft, która iuż raz zboże oddała, i na drugi rok podczas wiofny zafiewa lię” [108]; „,[Korzenie] około wielkiey nocy wyimuią fię i w miaftach z niemałym pożytkiem przedają" [576];

e) czasowniki osobowe w 3. osobie liczby mnogiej połączone z elipsą podmiotu, a w konsekwencji również z nieokreślonym wykonawcą czynności (31 przykładów), np.: „Sieią ięczmień pofpolity na Wiofnę dwa korce na mórg [...] Zwyczaynie fieią ięczmień na roli drugiego podziału, ale można go także fiać na roli trzeciego podziału” [444]; „Słomę zaś wyczaną miafto fiana ciołakom i owcom daią” [502]; „Kiedy doftałe fię Konopie pokażą tak że fię ziarno wykrufzyć może, wtenczas ie wyrywaią [...]. Ziarna kiianką zaraz obiiaią. Konopie zaś w fnopki związane na tychmiaft moczą, potym na fłońce wyftawiaia, naoftatek po kilka razy patykami miekcza" [506-507];

f) wreszcie grupa szósta - czasowniki w 1. osobie liczby mnogiej (27 przykładów), np.: „Nabywać maiętnośći przez fprawiedliwe tylko śrzodki powinniśmy” [31]; „Rzecz ieft niepodobna, ażebyśmy mogli przeyrzeć wfzyftkie potrzeby przypadkowe” [33]; „Len wfzyftkie inne fiewy dla fwoich włafności zda fię poliadać, bo od narodzenia precz całe życie bez płocien obeyść fię nie możemy, ba i po śmierci ciała nafze nimi okrywamy” [508]. Zatem te formy czasowników, które mają charakter inkluzywny (1. osoba liczby mnogiej), budują wspólnotę nadawczo-odbiorczą, włączają nadawcę i odbiorcę do jednej grupy, są stoso- 
wane rzadko i stanowią margines pozostałych form czasownikowych obecnych w poradni$\mathrm{ku}$ (w sumie jest to 8,1\% wszystkich analizowanych tu form czasownikowych). Nadawca właściwie nie podejmuje prób nawiązania bliskiego kontaktu z odbiorcą, tak charakterystycznego dla różnego typu poradników współczesnych (por. Wojtak 1994: 301-304).

Dokonany powyżej przegląd form czasownikowych obecnych we Wstepie do gospodarstwa pozwala na jeszcze jedno stwierdzenie - w poradniku dominuje nakłanianie pośrednie, perswazyjne nad nakłanianiem bezpośrednim, dyrektywnym ${ }^{8}$ : czasowniki w trybie rozkazującym (10 przykładów) oraz bezokoliczniki (38 przykładów) w funkcji rozkaźnika typowe dla nakłaniania dyrektywnego, stanowią tu mniejszość (14 \% analizowanych form czasownikowych). Większość poleceń formułowanych jest w sposób pośredni, przy użyciu czasowników modalnych (222 przykłady), co łagodzi wydźwięk dyrektywy. Nadawca, mający pozycję nadrzędną, pobudza odbiorcę do działania, wydaje polecenia, ale jednocześnie polecenia te są obudowane o różne akty przekonywania, takie jak:

a) ocenianie i wartościowanie, np.: „Pożyteczna też rzecz będzie...” [212]; „Niedobry ieft w Polfzcze zwyczay" [215];

b) wypowiedzenia asekuracyjne, np.: ,zda mi fię iż fłufzna rzecz ieft fzkodę lub pożytek, z złego lub dobrego orania przez nauki pokazać" [110];

c) nagromadzenie różnego rodzaju argumentów, np.: „trzeba rolą zagnoić, ażeby cząftki oleiowate, i folowe, które fię w gruncie znayduią, do tuczenia, wzroftu nafienia dopomagały” [106]; „Bez bydła żadna rola nie obeydzie fię, którego gnoy nawet do iey zaprawienia ieft potrzebny" [36];

d) wprowadzanie obrazowych porównań, zrozumiałych dla projektowanego odbiorcy, np.: ,[Ekonomia wieśniacza] ieft na k£ztałt matki, która wfzyftkich pańltw obywatelow, kupcow, fzlachtę, Panow, i panujących żywi, ta z wielką pracą i pilnością pomaga ziemi do wydania rożnych owocow" [36];

e) podkreślanie nowatorstwa proponowanych rozwiązań, sprawdzonych na Zachodzie, np.: „Znalażlzy te przyczyny [niepłodnośći ziemi] nie zawadzi zażyć fpofobow świeżo wynalezionych do uczynienia roli żyżnieyfzey, i lubo te fpofoby na inne kraie fą wynalezione, może iednak gofpodarz rozumny podług proporcyi zażyć do fwoiey roli” [37-38];

f) odwołanie się do doświadczenia życiowego czytelników, np.: „Ta rzecz ieft tak iafna z doświadczenia, iż o niey żaden Ekonom wątpić nie może” [106]; „Że ten kanał naywiękfzy tym fpofobem ma być robiony, fam rozum tego uczy, ponieważ woda na te mieyfca fpływa, które fą pochyłe" [209];

g) przytaczanie przysłów, będących nośnikiem tzw. mądrości ludowej, np.: „Iaka fieyba, takie żniwo" [437].

Zatem podsumowując, można zauważyć, że nadawca mimo iż sytuuje się w roli eksperta, podkreśla swoją przewagę i wyraźnie dystansuje się do odbiorcy (co pozostaje w sprzeczności ze współczesną literaturą poradnikową), to jednak nie próbuje czytelnikowi narzucić swego zdania, co jest charakterystyczne dla nakłaniania dyrektywnego, dla tekstów instruktażowych ${ }^{9}$, lecz usiłuje go zachęcić do podjęcia określonych działań, na różne sposoby przekonać do proponowanych rozwiązań.

\footnotetext{
${ }^{8}$ O dwóch aspektach nakłaniania: dyrektywnym i perswazyjnym patrz: Bralczyk 2001: 69-95.

${ }^{9}$ Obecność zdań rozkazujących i postulatywnych zbliża poradę do instrukcji. Decydujące są tu jednak wzajemne proporcje obu typów zdań oraz pozycja nadawcy: dominującego lub partnerskiego. (Por. Grabias
} 


\section{Aspekt poznawczy}

W analizowanym poradniku możemy obserwować szereg zabiegów, mających na celu uatrakcyjnienie lektury i ułatwienie jej mniej wyrobionemu odbiorcy. Nadawca, pamiętając o ograniczonej wiedzy o świecie mniej wykształconego czytelnika, dba o to, by jego tekst był łatwy i zrozumiały, a w tym celu: a) zasadniczo stosuje proste, niewyszukane słownictwo znane przeciętnemu czytelnikowi, a nowe, trudniejsze terminy (takie jak np. ekonomia, ekonomia wieśniacza, majętność, stużby, środki sprawiedliwe, środki niesprawiedliwe) czy nazwy mniej znanych, popularnych w ówczesnej Polsce roślin (np. tartofl, kalarepa) objaśnia, b) wielokrotnie odwołuje się do doświadczenia życiowego odbiorcy, c) przywołuje przykłady ilustracyjne, d) nadaje tekstowi może nieco schematyczną, ale za to przejrzystą formę, która ułatwia czytelnikowi poruszanie się po poradniku.

\section{Aspekt stylistyczny}

W świetle przeprowadzonej analizy poradnika gospodarskiego pomieszczonego w „Nowych Wiadomościach" można zauważyć, że dominującymi cechami stylowymi ${ }^{10}$ tego tekstu są: szablonowość (przejawiająca się w schematycznej kompozycji tekstu, w stosowaniu formulicznych wyrażeń, szablonów językowych), perswazyjność (przejawiająca się w nagromadzeniu środków służących przekonywaniu czytelnika do podjęcia określonych działań) i dyrektywność, czy lepiej, jak to określa Leszek Tymiakin (2007), subdyrektywność (przejawiająca się w nagromadzeniu w tekście licznych poleceń, ale przy założonej dowolności ich wykonania).

Poradnik, jak wskazują badacze (Żarski, Staniów 2010), mieści się w grupie tzw. tekstów użytkowych, które mogą wchłaniać elementy charakterystyczne dla różnych odmian stylowych polszczyzny. W wypadku analizowanego tekstu widać wyraźnie wpływ dwóch stylów - potocznego (niewyszukane słownictwo; proste konstrukcje składniowe; obecność przysłów) i przede wszystkim naukowego (wysoka organizacja tekstu, wyrazista segmentacja; pozycja nadawcy dystansującego się do odbiorcy; obecność terminologii z zakresu ekonomii; definiowanie nowych lub trudniejszych pojęć; wybiórczo przywoływanie obcojęzycznych (łacińskich i / lub niemieckich) odpowiedników polskich nazw roślin, np.: orkisz - łac. spelta, niem. Dinkel [438]). Być może takie nagromadzenie cech charakterystycznych dla prac naukowych jest efektem przeróbki jakiegoś tekstu specjalistycznego z zakresu rolnictwa i dostosowanie go do potrzeb czytelnika rodzącej się prasy popularnonaukowej - problem wymagałby jednak głębszych badań porównawczych.

Piśmiennictwo poradnikowe od zawsze znajdowało szerokie grono odbiorców. Zwłaszcza poradnictwo rolnicze, gospodarskie ma bardzo długą tradycję - źródeł tego typu po-

1997: 308-313).

${ }^{10}$ O teorii cech stylowych por. np. Wyderka 1990: 16-25. 
radników można doszukiwać się w dawnej literaturze kalendarzowej (Steczek-Czerniawska 2010). Czytelnicy szukali pomocy w rozwiązywaniu różnego rodzaju problemów, informacji niezbędnych do skutecznego działania, porad i instrukcji postępowania. Zapotrzebowanie na porady było i jest wysokie, ale współczesne teksty poradnikowe nastawione są na bliższe relacje z czytelnikiem, na skracanie dystansu, uatrakcyjnianie języka, co wyraźnie różni poradnik współczesny od tekstów dawnych.

\section{Bibliografia}

Aleksandrowska E., 1976, Mitzler de Kolof Wawrzyniec Krzysztof, w: Polski słownik biograficzny, red. E. Rostworowski, t. XXI, Wrocław, s. 389-392.

Biniewicz J., 2002, Ksztaltowanie się polskiego języka nauk matematyczno-przyrodniczych, Opole.

Bralczyk J., 2001, O języku polskiej propagandy politycznej lat siedemdziesiatych, Warszawa.

Dobrzyńska T., 1978, Delimitacja tekstu pisanego i mówionego, w: Tekst. Język. Poetyka. Zbiór studiów, red. M.R. Mayenowa, Wrocław, s. 101-118.

Ficek E., 2013, Poradnik. Model gatunkowy i jego tekstowe aktualizacje, Katowice.

Gajda S., 1988, Funkcjonowanie kategorii fleksyjnych czasownika we współczesnym polskim tekście naukowym, w: Stylistyczna akomodacja systemu gramatycznego, red. T. Skubalanka, Wrocław, s. $29-39$.

Grabias S., 1997, Język w zachowaniach społecznych, Lublin.

Klimowicz M., 1953, Mitzler de Kolof - redaktor i wydawca, w: R. Kaleta, M. Klimowicz, Prekursorzy oświecenia, Wrocław, s. 228-277.

Kurkowski J., 1994, Warszawskie czasopisma uczone doby Augusta III, Warszawa.

SL - S.B. Linde, Słownik języka polskiego, wyd. 2, t. I-VI, Lwów 1854-1860.

Starzec A., 1999, Współczesna polszczyzna popularnonaukowa, Opole.

Steczek-Czerniawska E., 2010, Porady praktyczne w kalendarzach kaliskich, w: Dobra rada nie zawada. Rady, porady, poradniki w języku, literaturze i kulturze, red. W. Żarski, B. Staniów, Koszalin, s. 155-163.

Tymiakin L., 2007, Nakłanianie subdyrektywne. Propozycja, prośba i rada $w$ realizacjach młodzieży gimnazjalnej. Zagadnienia wybrane, Lublin.

Witosz B., 2005, Genologia lingwistyczna. Zarys problematyki, Katowice.

Wojtak M., 1994, Przyjacielsko, miło, zrozumiale, czyli o stylu poradnika, w: Kształcenie porozumiewania się, red. S. Gajda, J. Nocoń, Opole, s. 301-304.

Wojtak M., 1999, Stylistyka tekstów użytkowych - wybrane zagadnienia, w: Język - teoria - dydaktyka, red. B. Greszczuk, Rzeszów, s. 253-263.

Wyderka B., 1990, Cechy składniowo-stylistyczne XVII-wiecznej prozy publicystycznej. Piśmiennictwo śląskie na tle ogólnopolskim, Opole.

Żarski W., Staniów B. (red.), 2010, Dobra rada nie zawada. Rady, porady, poradniki w języku, literaturze i kulturze, Koszalin.

Żmigrodzki P., 2009, Wprowadzenie do leksykografii polskiej, Katowice. 


\title{
AGNIESZKA SZCZAUS
}

\section{The language of a Handbook on Governance published in "Nowe Wiadomości Ekonomiczne i Uczone" (Up-to-date Economic and Scholarly News) (1758-1761)}

\begin{abstract}
Summary
The article analyses the structural, pragmatic, cognitive and stylistic aspects of a handbook entitled Introduction to governance, featured in the first Polish popular-scientific journal - "Nowe Wiadomości Ekonomiczne i Uczone" published in Warsaw in 1758-1761 by Wawrzyniec Mitzler de Kolof. It has been demonstrated that the text under analysis, which can be classified as a utility text, shows conspicuous elements of two styles - ordinary (unsophisticated vocabulary; simple syntactic structures; proverbs) and scholarly (pronounced text segmentation, perspective of the author setting himself aside from the recipient; economic terminology; defining new or more difficult concepts; references to foreign (Latin and/or German) counterparts of Polish names of plants).
\end{abstract}

Keywords: linguistics, genology, handbook 